13. Xiong Z. and Pires J. C. Karyotype and identification of all homoeologous chromosomes of allopolyploid Brassica napus and its diploid progenitors // Genetics. 2011. Vol. 187. P. 37-49.

14. Pedrosa-Harand A., de Almeida C.C., Mosiolek M. et al. Extensive ribosomal DNA amplification during Andean common bean (Phaseolus vulgaris L.) evolution // Theor. Appl. Genet. 2006. V.112. P. 924-933.

15. Long Q., Rabanal F.A., Meng D. et al. 2013. Massive genomic variation and strong selection in Arabidopsis thaliana lines from Sweden. Nat Genet 45: 884-890.

DOI 10.18699/GPB2020-53

\title{
Оценка полиморфизма ампелографической коллекции по реакци сортов на изменение агроклиматических показателей
}

Новикова Л.Ю. ${ }^{l *}$, д.с.-х.н., в.н.с., и.о. зав. отд. автоматизированных информационных систем генетических ресурсов растений; Наумова Л.Г. ${ }^{2}$, к.с.-х.н., в.н.с. лаборатории ампелографии.

${ }^{1}$ ФБНУ «ФИЦ Всероссийский институт генетических ресурсов растений им. Н.И. Вавилова», Санкт-Петербург, Россия;

${ }^{2}$ ВНИИ виноградарства и виноделия имени Я.И. Потапенко - филиал ФГБНУ ФРАНЦ, г. Новочеркасск, Россия.

*e-mail: l.novikova@vir.nw.ru

В условиях изменения климата важное значение приобретает анализ скоростей реакичи сортов винограда на изменения агроклиматических характеристик. На основе спецификаций ранее построенных регрессионных уравнений «среднего сорта» винограда рассчитаны коэффициченты регрессии для 292 сортов Донской ампелографической коллекции. Полученные скорости реакции на изменения агроклиматических факторов сравнили у групп сортов различного направления использования, таксономического происхождения, срока созревания с помощьью критерия Краскела-Уоллиса. Показано, что наибольшими скоростями характеризовались межвидовые гибриды с V. labrusca L. и V. amurensis Rupr., что связано с их чувствительностью к зимним и весенним температурам, и более поздние сорта.

Ключевые слова: ампелографическая коллекция, изменения климата, регрессионная модель, скорость реакции.

\section{Assessment of the ampelographic collection polymorphism}

based on the varieties reaction to changes in agroclimatic parameters

Novikova Liubov, Dr. Sci. in Agricul., leading researcher of the Department of automated information systems, Federal State Budgetary Scientific Institution «Federal Research Center the N.I. Vavilov All-Russian Institute of Plant Genetic Resources» (VIR), St.-Petersburg, Russia; Naumova Lyudmila, Cand. Agr.Sci., 
leading researcher of the Laboratory of ampelography, Federal State Budget Scientific Institution "Research Institute of Viticulture and Winemaking named after Ya.I. Potapenko», Novocherkassk, Russia.

In conditions of climate change, it is important to analyze the reaction rates of grape varieties to changes in agro-climatic characteristics. The regression coefficients for 292 varieties of the Don ampelographic collection were calculated based on the specifications of the previously constructed regression equations for the "average variety" of grape. The obtained reaction rates to changes in agroclimatic factors were compared in groups of varieties of different direction of use, taxonomic origin, and maturation period using the Kruskal-Wallis ANOVA by Ranks. It is shown that the highest speeds had the interspecific hybrids with $V$. labrusca L. and V. amurensis Rupr., due to their sensitivity to winter and spring temperatures; and later varieties.

Key words: ampelographic collection, climate change, regression model, reaction rate.

Научной основой программы адаптации виноградарства к текущим и ожидаемым климатическим изменениям является создание фенотипических баз данных генетических ресурсов винограда $[1,2]$, оценка трендов в динамике хозяйственно-ценных признаков сортов $[2,3]$, их моделирование и прогнозирование $[4,5]$. Нами ранее были построены агрометеорологические модели основных хозяйственно ценных признаков винограда [6-8]. Модели построены в разностях $[8,9]$ для приведения временных рядов наблюдений к стационарному виду. Показано, что межгодовая вариабельность продолжительности продукционного периода винограда определяется двумя агроклиматическими переменными: суммой температур выше $20^{\circ} \mathrm{C}$ и продолжительностью весеннего периода с температурами $10-15{ }^{\circ} \mathrm{C}$ [8]. Урожайность зависит от суммы эффективных температур выше $20{ }^{\circ} \mathrm{C}$ прошлого сезона, минимальной температурой зимы и продолжительностью весеннего периода с температурами $10-20{ }^{\circ} \mathrm{C}[6]$. Сахаристость и кислотность зависят от ГТК за период с температурами выше $15{ }^{\circ} \mathrm{C}$ [8]. Процент распустившихся глазков укрывных сортов зависит от минимальной температуры зимы и осадков июля предыдущего сезона; неукрывных - числа суток с температурами ниже минус $20{ }^{\circ} \mathrm{C}$ и осадков июля [7]. Анализ полиморфизма ампелографической коллекции показал, что основными дифференцирующими факторами являются направление использования, таксономическое происхождение и срок созревания сорта. Исследованные характеристики имеют у разных групп долговременные тренды одного знака, хотя их значения отличаются [10].

Задачей исследования является расчет и сравнительный анализ скорости реакции на изменение выделенных в комплексе моделей агроклиматических факторов для сортов разного направления использования, таксономического происхождения, сроков созревания. 
Объект и метод. Материалом для исследования послужила база данных наблюдений 1981-2017 гг. за 292 сортами винограда Донской ампелографической коллекции. Выборка состоит из 162 сортов технического и 130 столового направления использования. Представлены 4 группы сортов по таксономическому происхождению: 179 сортов Vitis vinifera L. (обозначаемые далее V), 20 сортов - межвидовые гибриды $V$. vinifera L. x V. labrusca L. (L), $37-V$. vinifera L. x V. amurensis Rupr. (A), 56 - гибриды с несколькими американскими видами (U). Представлены 7 групп сортов по срокам созревания. Для каждого сорта рассчитаны 9 коэффициентов регрессии на выявленные моделями агроклиматические факторы. Коэффициенты регрессии представляют собой скорости реакции хозяйственно ценных признаков сортов на изменения агроклиматических факторов. В сравнительном анализе использованы параметры сортов, имеющих не менее 5 лет измерений признака. Параметризация осуществлена в компьютерной программе VITIS TIME SERIES (Свидетельство о государственной регистрации программы для ЭВМ № 2019664805), разработанной нами для решения типовых задач агрометеорологического моделирования и прогнозирования хозяйственно ценных признаков винограда. Исследована достоверность различий параметров сортов контрастных групп непараметрическим критерием Краскела-Уоллиса (Kruskal-Wallis ANOVA by Ranks) в пакете Statistica 13.3.

Результат. Сорта столового (T) и технического (W) направления использования различались по скорости реакции продолжительности продукционного периода на рост сумм температур выше $20{ }^{\circ} \mathrm{C}(\mathrm{p}=0.004$; Т-минус 0.005 сут. $/{ }^{\circ} \mathrm{C} ; \mathrm{W}$ - минус 0.011 сут. $\left./{ }^{\circ} \mathrm{C}\right)$ и сокращение продолжительности весеннего периода с температурами $10-20{ }^{\circ} \mathrm{C}(\mathrm{p}=0.024 ; \mathrm{T}-0.211 ; \mathrm{W}-0.282)$, а также реакцией кислотности на рост ГТК 15 ( $\mathrm{p}=0.020 ; \mathrm{T}-2.403$ г/дм $3 / \mathrm{eд}$.; W3.027 г/дм $3 /$ ед.), скорости роста процента перезимовавших глазков на рост минимальной температуры зимы $(\mathrm{p}=0.000)$. Более сильная реакция технических сортов связана, возможно, с более поздними сроками их созревания по сравнению со столовыми (см. далее).

У сортов разного таксономического происхождения достоверно различалась скорость увеличения продолжительности продукционного периода в зависимости от роста продолжительности весеннего периода с температурой $10-15^{\circ} \mathrm{C}(\mathrm{p}=0.005)$. Группа гибридов с $V$. labrusca имела более высокую скорость реакции на рост температуры весны, чем остальные сорта, наименее реагировали сорта $V$. vinifera (средние скорости по группам, в порядке убывания: L-0.689; U-0.278; A-0.239; V-0.194 сут./ $\left.{ }^{\circ} \mathrm{C}\right)$. Это согласуется с выявленным нами фактом [10], что у группы гибридов с V. labrusca отмечен наибольший тренд к сокращению продукционного периода. Скорость роста урожайности в зависимости от роста минимальной температуры зимы $(\mathrm{p}=0.000)$ была наибольшей у гибридов с V. amurensis и c V. labrusca (L-0.481; 
A-0.293; V-0.110; U-0.103; кг $/$ куст $\left./{ }^{\circ} \mathrm{C}\right)$. Вероятно, это связано с тем, что в основном это морозостойкие сорта [11], зависящие от условий перезимовки и активно развивающиеся при низких температурах весны. Таким образом, по скорости реакции на изменения агроклиматических переменных выделились группы межвидовых гибридов с V. labrusca $u$ V. amurensis, контрастных с сортами $V$. vinifera.

У сортов разных сроков созревания скорость сокращения продолжительности вегетации при росте $\Sigma \mathrm{T}_{20}(\mathrm{p}=0.011)$ была наибольшей у более поздних групп (ранне-средние -0.15; средне-поздние -0.009; средние -0.008; сверхранние -0.007 ; ранние -0.004 ; очень ранние -0.002 сут. $\left.{ }^{\circ} \mathrm{C}\right)$. С ростом продолжительности вегетации наблюдается достоверное $(\mathrm{p}=0.000)$ усиление реакции кислотности на снижение ГТК 15 (сверхранние сорта 1.207 ; очень ранние 1.520; ранние 1.653 , ранне-средние 2.816 ; средние 3.184 ; средне-поздние 3.751 г/дм³/ед). По нашим наблюдениям, кислотность положительно коррелирует с продолжительностью продукционного периода [10].

Таким образом, наблюдался ряд достоверных отличий в скорости реакции групп сортов винограда различного направления использования, таксономического происхождения, срока созревания на изменения агроклиматических показателей. Наибольшими скоростями характеризовались межвидовые гибриды с $V$. labrusca $u$ V. amurensis, что связано с их чувствительностью к зимним и весенним температурам, и сорта более позднего срока созревания.

Благодарности: Работа выполнена при поддержке гранта РФФИ №18-016-00213.

\section{Список литературы}

1. Hausmann L., Maul E., Ganesch A., Kecke S., Töpfer R. The Vitis International Variety Catalogue and the European Vitis Database. INTEGRAPE 2019. Data Integration as a key step for future grapevine. Book of Abstracts Chania, Greece 25-28 March, 2019. 9. [Electronic resource] http://www.integrape.eu/images/pdf/CA17111-integrape2019.pdf.

2. Choudhury A., Jones J. Crop yield prediction using time series models. Journal of Economics and Economic Education Research. - 2014. - 15(3). - pp.53-67.

3. Jones G. Climate, Grapes, and Wine: Structure and Suitability in a Changing Climate // Acta Hort. 2012. - 931. - pp.19-28.

4. Molitor D., Junl J., Evers D., Hoffmann L., Beyer M. A high-resolution cumulative degree day-based model to simulate phonological development of grapevine // Am. J. Enol. Vitic. - 2014. - Vol. 65:1. - pp. 72-80.

5. Quenol H., Grosset M., Barbeau G., K.van Leeuwen, Hofmann M., Foss Ch., Irimia L., Rochard J., Boulanger J.-Ph., Tissot C., Mirand K. Adaptation of viticulture to climate change: high resolution observation of adaptation scenario for viticulture // Bull. de l'OIV. - 2014. - N1001-1002-1003 : Vol. 87. - pp. 385-406.

6. Наумова Л.Г., Новикова Л.Ю. Анализ тенденций изменений урожайности сортов винограда коллекции ВНИИВиВ им.Я.И. Потапенко // Виноделие и виноградарство. - 2014. - № 5. - С. $44-49$.

7. Новикова Л.Ю., Наумова Л.Г. Регрессионный анализ зимостойкости сортов 
винограда Донской ампелографической коллекции им. Я.И. Потапенко // Магарач. Виноградарство и виноделие. - 2018. - № 4. - С. 59-61.

8. Наумова Л.Г., Новикова Л.Ю. Использование метода последовательных разностей при создании агрометеорологических регрессионных моделей многолетних данных // Плодоводство и ягодоводство России. - 2018. - Т. 55. -С. 133 137. DOI 10.31676/2073-4948-2018-55-133-137.

9. Елисеева И.И., Курышева С.В., Костеева Т.В., Пантина И.В., Михайлов Б.А., Нерадовская Ю.В., Штрое Г.Г., Бартелс К., Рыбкина Л.Р. Эконометрика. М., 2007.

10. Novikova L.Yu., Naumova L.G. Structuring ampelographic collections by phenotypic characteristics and comparing the reaction of grape varieties to climate change // Vavilovskii Zhurnal Genetiki i Selektsii = Vavilov Journal of Genetics and Breeding. 2019. - 23(6). - C.772-779. - DOI 10.18699/VJ19.551.

11. Негруль А.М. Очерк семейства виноградных и его главных видов с их краткой хозяйственной характеристикой. Ампелография СССР. - Т.1. - М., 1946. C. 45-133.

DOI 10.18699/GPB2020-54

\section{Продуктивность и качество зерна у раннеспелых сортов мягкой яровой пшеницы в Северном Зауралье}

Новохатин В.В. *, к.с.-х.н., в.н.с.; Шеломенцева Т.В., н.с. НИИСХ Северного Зауралья - филиал ТюмНЦ СО РАН, г. Тюмень. *e-mail:vnovokhatin@bk.ru

Показаны сортовые различия по урожайности и основным технологическим показателям зерна. Выявлены сопряженные связи продуктивности с ее составляюшими, показателями качества зерна, поражаемостью патогенами и прорастанием зерна в колосе в предуборочный период. По урожайности и технологическим показателям зерна выделились сорта: Гренада, Тулунская 12, Тюменская 25, Ирень, Аделина, Новосибирская 31.

Ключевые слова: мягкая яровая пшеница, сорт, Урожайность, масса 1000 зерен, натура, протеин, клейковина.

\section{Productivity and quality of grain in early mature varieties of soft spring wheat in the northern Trans-Ural}

Novokhatin V.V., candidate of agricultural sciences, leading researcher, TV Shelomentseva, ns NIISH North-Urals - a branch of the Tyumen Scientific Center of the SB RAS, Tyumen, Russia.

*e-mail:vnovokhatin@bk.ru

Varietal differences in yield and main technological indicators of grain are 